\title{
Pengaruh Kualitas Produk Terhadap Kepuasan Pelanggan pada PT. Gema Air Masindo
}

\author{
Toto Widiyanto
}

FIPPS Universitas indraprasta PGRI Jakarta

E-mail: unindra103@gmail.com

\begin{abstract}
Abstrak: Metode yang digunakan untuk mengetahui pengaruh kualitas produk terhadap kepuasan pelanggan adalah kuesioner. Dalam metode ini, data yang dikumpulkan melalui kuesioner dibagikan kepada responden Gema Air Masindo kemudian diuji dalam pengujian hipotesis. Dari hasil perhitungan koefisien korelasi terbukti adanya korelasi kuat antara kualitas produk terhadap kepuasan pelanggan Gema Air Masindo. Sedangkan hasil perhitungan uji hipotesis dengan sampel $t$ menunjukkan bahwa $t=6,692$ dan $t$ tabel $=2,060$ antara $t$ hitung dengan $t$ tabel yang menghasilkan $t$ hitung $>t$ tabel yaitu 6,692>2,060. Dengan hasil ini, dapat dikatakan bahwa Ha diterima dan Ho ditolak, yang berarti ada pengaruh yang signifikan antara kualitas produk $(\mathrm{X})$ dan kepuasan pelanggan $(\mathrm{Y})$. Setelah penulis melakukan penelitian terhadap kualitas produk terhadap kepuasan pelanggan, maka kesimpulannya adalah ada pengaruh yang signifikan antara kualitas produk terhadap kepuasan pelanggan.
\end{abstract}

Kata Kunci: Kualitas produk, kepuasaan, pelanggan.

UTILITY: Jurnal IImiah Pendidikan dan Ekonomi

Website : http://journal.stkipnurulhuda.ac.id/index.php/utility

Permalink: https://journal.stkipnurulhuda.ac.id/index.php/utility/article/view/285

How to cite (APA): Widiyanto, T. (2018, February 1). Pengaruh Kualitas Produk Terhadap Kepuasan Pelanggan pada PT. Gema Air Masindo. UTILITY: Jurnal IImiah Pendidikan Dan Ekonomi, 2(1), 64-71.

This is an open access article distributed under the terms of the Creative Commons Attribution 4.0 International License, which permits unrestricted use, distribution, and reproduction in any medium, provided the original work is properly cited.

\section{PENDAHULUAN}

Kualitas produk merupakan salah satu faktor penentu di dalam tingkat kepuasan yang diperoleh pelanggan setelah melakukan pembelian dan pemakaian suatu produk. Pengalaman yang baik atau buruk terhadap suatu produk akan mempengaruhi pelanggan untuk melakukan pembelian kembali suatu produk. Hal ini membuat perusahaan berusaha memfokuskan pada 
kualitas produknya dapat sesuai dengan kebutuhan pelanggan agar pelanggan selalu puas dengan produk yang telah diproduksi oleh perusahaan tersebut.

Kualitas produk memiliki peran penting dalam membantu meningkatkan kepuasan pelanggan dan meningkatkan penjualan suatu perusahaan.pentingnya kualitas produk yang dirasakan oleh pelanggan akan mempengaruhi keputusan pembelian, apabila pelanggan merasa puas dengan produk yang dibeli, maka akan ada kecenderungan pelanggan akan melakukan pembelian kembali dan akhirnya menjadi pelanggan yang setia.

Kepuasan pelanggan memiliki hubungan yang positif terhadap pembelian produk kembali dan semakin tinggi level kepuasan maka akan tercipta loyalitas yang baik. Pada dasarnya kepuasan merefleksikan dampak kinerja suatu produk atau jasa terhadap perasaan pelanggan. Pelanggan merasakan apakah konsumsi yang dilakukannya telah memenuhi kebutuhan dan keinginannya, apabila konsumsi tersebut menyenangkan atau tidak. Dalam hal ini produk maupun jasa memegang peranan penting dalam pemasaran yaitu harus sesuai dengan kebutuhan dan keinginan pelanggan sehingga dapat memuaskan pelanggan.

Pelanggan merupakan mitra utama bagi pemasar. Seseorang dapat dikatakan sebagai pelanggan apabila orang tersebut mulai membiasakan diri untuk membeli produk dan jasa yang ditawarkan oleh badan usaha. Kebiasaan tersebut dapat dibangun melalui pembelian berulang dalam jangka waktu tertentu, apabila dalam jangka waktu tertentu tidak melakukan pembelian ulang maka orang atau badan usaha tersebut tidak dapat dikatakan sebagai pelanggan tetapi sebagai pembeli.

Kepuasan pelanggan merupakan kunci dalam menciptakan loyalitas pelanggan. Banyak manfaat yang diterima oleh perusahaan dengan tercapainya tingkat kepuasan pelanggan yang tinggi, yakni selain dapat meningkatkan loyalitas pelanggan tapi juga dapat mencegah terjadinya perputaran pelanggan, mengurangi sensitivitas pelanggan terhadap harga, mengurangi biaya kegagalan pemasaran, mengurangi biaya operasi yang diakibatkan oleh meningkatnya jumlah pelanggan, meningkatkan efektivitas iklan, dan meningkatkan reputasi bisnis.

Pemasar pada umumnya menginginkan bahwa pelanggan yang diciptakannya dapat dipertahankan selamanya. Ini bukan tugas yang mudah mengingat perubahan-perubahan dapat terjadi setiap saat, baik perubahan pada diri pelanggan seperti selera maupun aspek aspek psikologis serta perubahan 
kondisi lingkungan yang mempengaruhi aspek-aspek psikologis, social dan kultural pelanggan.

Terdapat beberapa keuntungan strategik bagi perusahaan tentang pentingnya mempertahankan kepuasan pelanggan, biasanya imbalan dari kepuasan pelanggan bersifatt jangka panjang dan kumulatif. Jadi semakin individu puas terhadap produk, semakin besar pula laba yang diperoleh perusahaan dari seorang dari pelanggan. Dipertahannkannya pelanggan akan mengurangi usaha mencari pelanggan baru, memberikan umpan balik positif kepada organisasi, dan kepuasan pelanggan memiliki hubungan positif dengan profitabilitas, memberikan peluang pembelian ulang yang konsisten, perluasan lini produk yang dikonsumsi, penyebaran berita baik (positive word of mounth), menurunnya elastisitas harga, dan menurunnya biaya promosi dalam ranggka menarik pelanggan baru.

PT. Gema Air Masindo adalah perusahaan yang bergerak dibidang manufacturing. Pada dasarnya yang menjadi usaha inti dari PT. Gema Air Masindo ini adalah memproduksi Jig and Dies, akan tetapi selain terfokus pada bisnis utamanya PT. Gema Air Masindo juga menyediakan jasa serta pembuatan produk single part dan mass pro.

Pihak PT. Gema Air Masindo harus mampu mempertahankan dan meningkatkan kualitas produknya, demi profitabilitas perusahaannya dimasa mendatang. Diperlukan pemahaman yang serius dari pihak PT. Gema Air Masindo terhadap faktor-faktor yang dapat mempengaruhi kualitas produk, untuk terus meningkatkannya dalam rangka mempertahannkan dan meningkatkan kepuasan pelanggan. Penelitian ini akan menguji faktor-faktor yang mempengaruhi kepuasan pelanggan. Karena kepuasan pelanggan dapat meningkatkan intensitas membeli dari pelanggan.

Faktor faktor yang mempengaruhi kualitas produk dari PT. Gema Air Masindo ini ialah man power atau biasa disebut dengan sumber daya manusia, visual atau keindahan produk,. Assembly atau perakitan, Accuracy atau disebut juga dengan pengukuran, QC yang biasa disebut dengan Quality Control, barang yang dibuat akan dicek terdahulu oleh quality control, maka PT. Gema Air Masindo harus mempunyai sumber daya manuasia yang teliti agar produkproduk yang dikeluarkan dari PT. Gema Air Masindo adalah produk yang berkualitas baik. Berdasarkan uraian diatas peneliti tertarik untuk meneliti, 
dengan judul "pengaruh kualitas produk terhadap kepuasn pelanggan PT Geema Air Masindo"

\section{METODE}

Menurut Sugiyono (2012:2) “Metode penelitian pada dasarnya merupakan cara ilmiah untuk mendapatkan data dengan tujuan dan kegunaan tertentu. Berdasarkan hal tersebut terdapat empat kata kunci yang perlu diperhatikan yaitu, cara ilmiah, data, tujuan dan kegunaan. Penelitian ini dimaksudkan untuk memproses data yang sesuai dengan arahan dan tujuan penelitian.

Penelitian ini menggunakan desain kuesioner guna untuk mendapatkan informasi dengan cara memperoleh data sekunder. Maka jenis penelitian yang digunakan desain penelitian kuantitatif, data yang digunakan pada penelitian ini adalah data sekunder yaitu jenis data yang diperoleh yaitu melalui pengutipan data (analisis data penjualan) informasi dari dokumen yang berkaitan dan literatur-literatur yang sesuai dengan penelitian.

\section{HASIL DAN PEMBAHASAN}

Data hasil dari perhitungan antara dua variabel $\mathrm{X}$ dan $\mathrm{Y}$ dari 27 responden Tabel.1. perhitungan variabel $\mathrm{X}$ dan $\mathrm{Y}$

\begin{tabular}{cccc}
\hline No. & Variabel & $\begin{array}{c}\text { Alpha } \\
\text { Chronbach }\end{array}$ & r tabel \\
\hline 1 & Kualitas Produk (Variabel X) & 0,661 & 0,396 \\
\hline 2 & $\begin{array}{c}\text { Kepuasan Pelanggan } \\
\text { (Variabel Y) }\end{array}$ & 0,605 & 0,396 \\
\hline
\end{tabular}

a) Uji Validitas

Tabel.2. Uji Validitas

\begin{tabular}{|c|c|c|c|c|}
\hline $\begin{array}{l}\text { Butir } \\
\text { Dalam }\end{array}$ & Koefisien & $\begin{array}{l}\text { Nilai } \\
\text { Kritis }\end{array}$ & $\begin{array}{l}\text { Taraf } \\
\text { Sig. }\end{array}$ & \multirow{2}{*}{ Keterangan } \\
\hline Kuesioner & $\begin{array}{l}\text { Korelasi ( } \mathrm{r} \\
\text { ) }\end{array}$ & ( $r$ tabel & $\begin{array}{l}(\alpha= \\
0,05)\end{array}$ & \\
\hline \multicolumn{2}{|c|}{$\mathrm{X}$ (Kualitas Produk) } & 0,396 & 0,05 & VALID \\
\hline \multicolumn{2}{|c|}{ Y (Kepuasan Pelanggan) } & 0,396 & 0,05 & VALID \\
\hline
\end{tabular}


b) Uji Reabilitas

Tabel. 3. Uji Realibilitas

\begin{tabular}{cccc}
\hline No. & Variabel & $\begin{array}{c}\text { Alpha } \\
\text { Chronbach }\end{array}$ & r tabel \\
\hline 1 & Kualitas Produk (Variabel X) & 0,661 & 0,396 \\
\hline 2 & $\begin{array}{c}\text { Kepuasan Pelanggan } \\
\text { (Variabel Y) }\end{array}$ & 0,605 & 0,396 \\
\hline
\end{tabular}

c) Analisis Regresi Linier Sederhana

Persanaan regresi yang diperoleh ialah $\hat{Y}=4,938+0,864 X$, yang dapat diartikan jika variabel kepuasan (variabel $\mathrm{x}$ ) naik satu kali, maka variabel kepuasan pelanggan (variabel y) akan naik sebesar 0.864 kali.

d) Analis Korelasi Sederhana

$$
\begin{aligned}
r & =\frac{n\left(\sum \mathrm{xy}\right)-\left(\sum \mathrm{X}\right)\left(\sum \mathrm{Y}\right)}{\sqrt{\left[n \cdot \sum x^{2}-\left(\sum x\right)^{2}\right]\left[n \sum Y^{2}-\left(\sum Y\right)^{2}\right]}} \\
r & =\frac{27(44131)-(1098)(1082)}{\sqrt{\left[27.44802-(1098)^{2}\right]\left[27.43534-(1082)^{2}\right]}} \\
r & =0,803
\end{aligned}
$$

Artinya, koefisien korelasi sebesar 0,803 yang membuktikan adanya pengaruh kuat dan positif antara kualitas produk terhadap kepuasan pelanggan

e) Koefisien Determinasi
KD $: r^{2} \times 100 \%$
KD $: 0,803^{2} \times 100 \%$
KD $: 64 \%$

Artinya kontribusi pengaruh kualitas produk sebesar 64\%, sedangkan 36\% merupakan variabel lain selain dari variabel dalam penelitian ini.

f) Uji T

$$
\begin{aligned}
\mathrm{T}_{\text {hitung }} & =\frac{r \sqrt{n-2}}{\sqrt{\left(1-r^{2}\right)}} \\
\mathrm{T}_{\text {hitung }} & =\frac{0,803 \sqrt{27-2}}{\sqrt{\left(1-0,803^{2}\right)}}
\end{aligned}
$$


$\mathrm{T}_{\text {hitung }}=6,692$

Perhitungan $\mathrm{t}$ tabel :

1) Nilai t tabel

Dipilih level of significance tertentu $\alpha=0.05$

Derajat kebebasan $(\mathrm{dk})=27-2=25$

$\mathrm{T}_{\text {tabel }}=\mathrm{t}_{(\alpha / 2)(\mathrm{n}-2)}=\mathrm{t}_{0,05: 25}=2,060$

2) Kriteria penerimaan hipotesis

- $H o=$ diterima jika $t_{\text {hitung }}<2,060$ atau $t_{\text {hitung }}>2,060$

$\mathrm{Ha}=$ ditolak jika $\mathrm{t}_{\text {hitung }}>2,060$ atau $\mathrm{t}_{\text {hitung }}<2,060$

- $\mathrm{T}_{\text {test }}=6,692$

Jadi $\mathrm{t}_{\text {test }}>\mathrm{t}_{\text {tabel }}=6,692>2,060$

Maka artinya $\mathrm{H} 0$ ditolak, Ha diterima

Berdasarkan perhitungan diatas, maka diperoleh $t_{\text {hitung }}>t_{\text {tabel }}$ yaitu, 6,692 $>$ 2,060 yang berarti Ha diterima dan Ho ditolak. Sehingga dapat diketahui bahwa adanya pengaruh yang signifikan antara kualitas produk dengan kepuasan pelanggan.

\section{SIMPULAN}

Dari hasil pengolahan data secara kuantitatif yang diperoleh melalui survey menggunakan kuesioner kepada pelanggan PT. Gema Air Masindo yang berjumlah 27 orang sebagai responden, termasuk data yang diperoleh dari dokumen perusahaan maupun observasi langsung ke lapangan tentang responden tersebut, terkait dengan penelitian ini " Pengaruh Kualitas Produk Terhadap Kepuasan Pelanggan pada PT. Gema Air Masindo di Citeureup Bogor", dapat disimpulkan sebagai berikut :

1. Tingkat kualitas produk (variabel X) di PT. Gema Air Masindo tinggi sesuai hasil analis deskriptif yang diperoleh.

2. Tingkat kepuasan pelanggan (variabel Y) di PT. Gema Air Masindo tinggi sesuai hasil analisis deskriptif yang diperoleh.

3. Berdasarkan hasil perhitungan analis uji $t$, besar $t_{\text {hitung }}>t_{\text {tabel }}$ yaitu 6,692 $>$ 2,060. Sehingga Ho ditolak, sedangkan Ha diterima dengan kata lain terdapat pengaruh antara kualitas produk terhadap kepuasan pelanggan PT. Gema Air Masindo.

4. Berdasarkan hasil perhitungan korelasi sederhana, menunjukan bahwa besar $r=0,803$. Sehingga hal ini menunjukan tingkat hubungan antara 
variabel kualitas produk PT. Gema Air Masindo dengan kepuasan pelanggan PT. Gema Air Masindo adalah sangat reliabel.

5. Pengaruh kualitas produk PT. Gema Air Masindo terhadap kepuasan pelanggan PT. Gema Air Masindo sebesar 64\% dan sisanya yakni 36\% dipengaruhi oleh faktor-faktor lain seperti: promosi, harga, tempat dan sebagainya.

6. Jika terjadi kenaikan variabel kualitas produk satu kali, maka akan terjadi kenaikan juga pada variabel kepuasan pelanggan sebesar 0,864 kali.

7. Adanya pengaruh yang signifikan antara kualitis produk (X) terhadap kepuasan pelanggan (Y), sesuai dengan hasil uji hipotesis yang diperoleh yaitut hitung lebih besar dari nilai $t$ tabel.

8. Dalam hasil penelitian ini dapat dinyatakan bahwa variabel kualitas produk secara positif mempengaruhi kepuasan pelanggan. Hal ini menunjukan bahwa semakin baik kualitas produk PT. Gema Air Masindo maka dapat mengakibatkan semakin naik kepuasan pelanggan di PT. Gema Air Masindo, Citeureup.

\section{REFERENSI}

Riduwan. 2008. Metode \& Teknik Menyusun Tesis. Bandung: Alfabeta.

Ramli, Ishak. 2010. Manajemen Pabrik Beautiful Management with QCDSM. Jakarta: Kompas Gramedia.

Mamang, Etta dan Sopiah. 2013. Perilaku Konsumen. Yogyakarta: CV Andi Offset.

Nurfarkhana, Anna dan Widati, Endah. 2013. Manajemen Pemasaran 2. Jakarta: Unindra Press.

Suryono dan Suhendar, Endang. 2014. Manajemen Produksi dan Operasi. Jakarta: Mitra Wacana Media.

Gaspersz, Vincent. 2007. Membangun Tujuh Kebiasaan Kualitas Dalam Praktek Bisnis Global. Jakarta: PT. Gramedia Pustaka Utama.

Paul, Peter. 2006. Consumer Behavior Perilaku Konsumen dan Strategi Pemasaran Jilid 4. Jakarta: Erlangga. 
Wahyudi, Setiyono dan Setyorini, Yuyut. 2006. Pemasaran Jasa dan Kualitas Pelayanan. Malang: Bayumedia Publishing.

Sudaryono. 2014. Perilaku Konsumen Dalam Perspektif Pemasaran. Jakarta: Lentera Ilmu Cendikia.

Kotler, P. dan Gary Amsrong. 2001. Prinsip-Prinsip Pemasaran, Jilid 1, Edisi ke-8. Jakarta: Erlangga 